\title{
Analisis Mekanisme Praktik Jual Beli Followers Dalam Perspektif Ekonomi Islam Di Media Sosial Instagram
}

\author{
Nindi Apridha Jamil ${ }^{1}$, Asep Dede Kurnia ${ }^{2}$, Jalaludin ${ }^{3}$ \\ ${ }^{1,2,3}$ STIES Indonesia Purwakarta \\ ${ }^{1}$ nindiapjam@gmail.com \\ 2asepjibri193@yahoo.com \\ 3jalaludinstiesip@gmail.com
}

\begin{abstract}
Abstrak - Tujuan dari penelitian ini adalah untuk mengetahui mekanisme praktek jual beli followers di media sosial Instagram dan untuk mengetahui mekanisme praktek jual beli followers di media sosial instagram dalam perspektif ekonomi Islam. Jenis penelitian yang digunakan adalah penelitian lapangan (field research), adapun pendekatan yang digunakan dalam penelitian ini adalah pendekatan deskriptif-kualitatif. Mekanisme yang dilakukan dalam praktik jual beli followers ini dilakukan seperti jual beli online dan Mekanisme praktik jual beli followers dalam perspektif ekonomi Islam, jual beli followers Jika ditinjau dari jual beli secara umum berdasarkan Fatwa Dewan Syariah Nasional- Majelis Ulama Indonesia Nomor 110/DSN-MUI/IX/2017 melalui tabel kesesuaian adanya ketidaksesuaian syariah dalam jual beli Followers. Jual beli followers ini termasuk kedalam jual beli yang tidak sah yang disebabkan objek yang dipejualbelikan tidak jelas wujud maupun dalam hal status kepemilikan objek tersebut bukan seutuhnya milik penjual atau tidak adanya ijin dari si pemilik. Maka syarat dan rukun dari jual beli tersebut tidak terpenuhi. Kemudian kedua, dilihat dari sisi manfaat dalam jual beli followers ini cenderung banyak mendatangkan kemudharatan serta rawan terjadinya penipuan dan dalam transaksi ini mengandung unsur mengambil keuntungan dalam kesempitan yang mengandung tipu daya sehingga mengakibatkan salah satu pihak merugi. Hal tersebut dapat dilihat dari obyek yang diperjualbelikan tidak sesuai dengan kesepakatan di awal sehingga terdapat kerugian dari pihak pembeli mengenai berkurangnya jumlah followers yang dibelinya secara cepat tanpa diketahui pihak pembeli di awal waktu dan tidak adanya jaminan atau garansi dari pihak penjual untuk followers aktif. Jual beli ini tetap ada manfaatnya namun bersifat fiktif, bahkan dapat menimbulkan penipuan yang dapat dirugikan masyarakat dan konsumen.
\end{abstract}

Kata Kunci: Mekanisme, Jual Beli, Followers, Instagram.

Abstract - The purpose of this research is to find out the mechanism of buying and selling followers practice on Instagram social media and to find out the mechanism of buying and selling followers practice on Instagram social media in the perspective of Islamic economics. The type of research used is field research, while the approach used in this study is a descriptive-qualitative approach. Mechanism that is carried out in the practice of buying and selling followers is carried out such as buying and selling online and mechanism of buying and selling followers practice in an Islamic economic perspective, buying and selling followers If viewed from general buying and selling based on the National Sharia Council Fatwa - Indonesian Ulema Council Number 110 / DSN-MUI / IX / 2017 through the suitability table of Islamic incompatibility in buying and selling Followers. Buying and selling followers is included in unauthorized buying and selling caused by the object being bought and sold is not clear form or in terms of ownership status of the object is not completely owned by the seller or the lack of permission from the owner. Then the terms and conditions of the sale and purchase are not met. Then second, viewed from the side of the benefits in buying and selling followers tend to bring a lot of kemudharatan and prone to fraud and in this transaction contains elements of taking 


\section{EKSISBANK Vol. 4 No. 1 Juni 2020}

advantage in the narrowness that contains deception so as to result in one party losers. This can be seen from the object being traded that is not in accordance with the agreement at the beginning, so there is a loss on the part of the buyer regarding the reduction in the number of followers he bought quickly without being noticed by the buyer at the beginning of time and there is no guarantee or guarantee from the seller for active followers. Buying and selling is still beneficial but fictitious, and can even lead to fraud that can be harmed by the public and consumers.

Key words: Mechanism, Buy and Sell, Followers, Instagram

\section{PENDAHULUAN}

Transaksi Jual beli merupakan kegiatan manusia yang terus mengalami perkembangan dari masa ke masa. Sebagaimana kita ketahui bahwa pada saat ini aktivitas ekonomi sebagai salah satu aspek terpenting dalam kehidupan manusia berkembang cukup dinamis dan begitu cepat. Terlebih dengan perkembangan alat dan perangkat komunikasi dan informasi yang sedemikian kencang. Hal ini membuat aktivitas ekonomi semakin variatif dan semakin intens dilakukan. Kreativitas pengembangan model transaksi dan produk semakin tinggi (Mustofa, 2016).

Kajian hukum Islam dari jaman ke jaman terus berkembang termasuk dalam hal muamalah. Salah satu contohnya adalah jual beli yang mengalami banyak Perkembangan baik dari segi konsep maupun objek yang diperjualbelikan (Romansyah, 2015).

Perubahan-perubahan konsep dalam melakukan perniagaan tersebut terjadi karena kemajuan ilmu pengetahuan dan teknologi serta kebutuhan manusia itu sendiri, sehingga hukum Islam pun harus bisa fleksibel mengikuti jaman dan kondisi masyarakat.

Teknologi yang semakin maju, menjadikan perniagaan tidak lagi harus menggunakan cara tradisional, mengumpulkan dagangan di pasar atau menawarkan kepada setiap orang yang ditemui. Akan tetapi, sekarang perniagaan dapat dilakukan lebih mudah melalui internet. Pemanfaatan dunia online untuk menjalankan bisnis atau lebih dikenal dengan e-commerce sudah cukup terkenal dikalangan pengusaha seiring meningkatnya pengguna internet di tanah air. Belanja secara online telah menjadi kebiasaan dan gaya hidup. Oleh karena itu media sosial atau yang sering disebut jejaring sosial merupakan salah satu hal yang paling dinamis di dunia saat ini, tidak lagi hanya menjadi jembatan komunikasi antar manusia di dunia maya, akan tetapi sosial media sudah berubah dengan berbagai fungsi. Banyak orang memanfaatkan sosial media untuk memenuhi beragam kebutuhan, mulai dari media mengekpresikan diri, mengejar ketenaran, menggalang dukungan, hingga mencari penghasilan (Herdani, 2014).

Media sosial menjadi satu bagian penting di kehidupan manusia di era digital ini, Perusahaan dan pebisnis kini marak membangun wadah sosial sendiri dan mengajak siapa yang berminat untuk berpartisipasi dengan memberi kontribusi dan umpan balik, komentar, tanggapan, mengisi polling dan survei, serta membagi informasi dalam waktu yang cepat mengenai suatu produk. Kemajuan perkembangan teknologi internet, komputer tablet dan smartphone membuat media sosial ikut tumbuh dengan pesat (RI, 2014).

Fungsi dari media sosial dalam berbisnis digunakan sebagai media promosi produk-produk (Irma, 2017). Salah satu jual beli yang menggunakan teknologi sebagai medianya yaitu jual beli online. Jual beli secara online banyak dilakukan oleh sebagian masyarakat karena kemudahannya dalam melakukan transaksi yaitu tidak harus bertemunya secara langsung antara penjual maupun pembeli. Namun dengan semakin berkembangnya jaman, jual beli online saat ini tidak hanya mencakup jual beli barang keperluan sehari-hari saja, tetapi ada pula transaksi yang menjual belikan berupa penambahan followers di media sosial instagram. Pada umumnya pembeli menggunakan followers untuk kepentingan bisnis terutama bagi mereka yang mempunyai online shop, karena dengan semakin banyaknya followers maka otomatis akan semakin banyak pula orang yang mengenal onlineshop-nya tersebut. Namun tidak sedikit juga dari mereka merupakan perorangan yang menggunakan followers tersebut sebagai ajang untuk mempopulerkan dirinya sendiri agar terkenal dikalangan pengguna instagram lainnya (Anisa, 2018). 


\section{EKSISBANK Vol. 4 No. 1 Juni 2020}

Tata cara yang dilakukan dalam jual beli followers tidak jauh berbeda dengan jual beli online lainnya yaitu dengan melakukan pembayaran terlebih dahulu kemudian penjual baru akan memproses apa yang di inginkan oleh pembeli baik itu followers. Proses yang dilakukan oleh penjual biasanya membutuhkan waktu satu hari untuk menambah followers yang dipesan oleh para pembeli yang kemudian akan di tambahkan jumlahnya pada akun instagram yang diinginkan. Dalam prosesnya yang online terdapat beberapa harga yang memang dijadikan acuan dalam setiap penambahan followers yaitu untuk harga followers pasif dapat dikenakan biaya Rp. 25.000/ 500 Followers dan untuk harga followers aktif dikenakan biaya berkisar $\mathrm{Rp}$. 50.000/ 500 followers nya dan dilakukan setelah adanya proses transfer pada bank yang telah ditentukan dan proses penambahan followers akan segera diproses (Haris.com, 2019).

1.1 Harga Followers

\begin{tabular}{|l|c|}
\hline Followers & $\begin{array}{c}\text { Harga /500 } \\
\text { Followers }\end{array}$ \\
\hline Pasif & Rp. 25.000 \\
\hline Aktif & \pm Rp. 50.000 \\
\hline
\end{tabular}

Islam secara khusus mensyaratkan objek yang dapat diperjualbelikan diantaranya adalah, barang tersebut harus berwujud, walaupun keterangannya memberi contoh tidak memperbolehkan menjual ikan yang masih berenang di laut, atau buah yang masih belum jelas kapan matangnya, kemudian barang tersebut harus memiliki manfaat (Rasjid, 2010).

Jual beli followers, barang yang diperjualbelikan adalah bukan barang yang nyata melainkan berupa penambahan followers pada akun seseorang pembeli. Penambahan sebuah followers adalah sebuah objek transaksi yang tidak berwujud, nilai dan manfaat sebuah followers tersebut juga menjadi suatu hal yang perlu dikaji dan tata cara seorang penjual mendapatkan akun instagram yang nantinya akan mereka jual sebagai followers, dengan resiko yang akan ditanggung oleh pembeli ketika para followers tersebut berhenti mem-follownya (Anisa, 2018). Disini menarik sekali untuk diteliti dari sisi jual beli dalam pandangan ekonomi Islam. Menurut peneliti, jual beli semacam followers perlu dikaji lebih lanjut karena sesuatu yang diperjualbelikan mengandung unsur penipuan, dimana followers tersebut bukan merupakan followers sejati atau benar-benar ingin menjadi followersnya, sedangkan followers tersebut dimanfaatkan untuk kepentingan berbisnis bagi pembeli. Hal tersebut merupakan model perdagangan baru yang perlu ditinjau dari segi ekonomi Islamnya.

Dilihat dari pemaparan diatas penulis tertarik meneliti dan mengkaji lebih dalam tentang jual beli followers di media sosial Instagram dalam perspektif Islam. Maka dari itu, penulis mengambil judul penelitian "Analisis Praktik Jual Beli Followers di Media Sosial Instagram dalam Perspektif Ekonomi Islam".

Instagram adalah layanan aplikasi berbagai foto yang pertama kali dapat diunduh di App Store pada Apple, dan hanya pengguna iOS lah yang dapat menggunakan aplikasi Instagram ini awalnya. Instagram memfasilitasi penggunanya untuk mengambil foto, mengedit foto dan menyebarkan foto yang kita unggah ke sosial media lainnya (Twitter, Facebook, Tumblr, Flickr) (@TrikPhotoshopID \& @BisnisAnakMuda, 2014). Instagram mempunyai fitur-fitur diantaranya likes, followers dan viewers. Likes adalah suka atau menyukai foto dan video pada Instagram, caranya klik dua kali pada foto atau video di Instagram atau klik tanda love. Followers adalah pengikut, yaitu orang yang mengikuti, jadi bila posting sesuatu di Instagram, baik foto atau video maka followers yang akan pertama kali melihat dibandingkan bukan followers kita. Selanjutnya adalah viewer, viewers adalah penonton dari video yang di posting di Instagram. Seiring berkembangnya teknologi Instagram menjadi salah satu wadah yang sangat bermanfaat untuk para pembisnis maupun untuk menaikan popularitas dan followers menjadi salah satu faktor yang mendukung terjadinya hal tersebut. Munculah berbagai bisnis diataranya adalah jual beli followers, mekanisme dalam penjualan followers sama saja seperti jual beli online pada umumnya. Melakukan proses pemesanan, pembayaran, proses dan followers bertambah.

Muamalat merupakan kegiatan atau transaksi yang dilaksanakan berdasarkan hukum Islam. Artinya, segala jenis transaksi harus sesu ai dengan ketentuan nash (Bombang, 2013; Khoiriyah, 2018; Munib, 2018). Selain itu, setiap transaksi juga harus sesuai dengan kaidah kaidah 


\section{EKSISBANK Vol. 4 No. 1 Juni 2020}

hukum Islam. Beberapa kaidah atau prinsip hukum Islam yang dapat dijadikan sebagai pedoman dalam bermuamalat adalah sebagai berikut (Basyir, 2000):

a. Pada dasarnya segala bentuk muamalat adalah mubah, kecuali yang ditentukan lain al-Qur'an dan Hadis. Kaidah ini menerangkan bahwa, segala tindakan hukum atau perjanjian boleh dilakukan sejauh tidak ada larangan mengenai perjanjian tersebut.
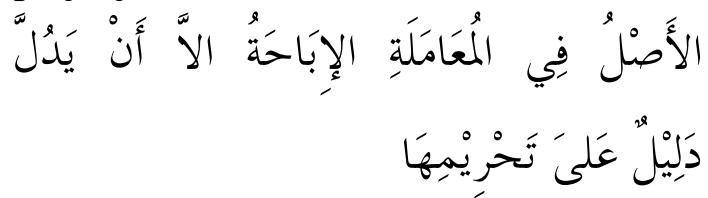

"Hukum asal semua bentuk muamlah adalah boleh dilakukan kecuali ada dalil yang Mengharamkannya."

b. Muamalat yang dilakukan atas dasar suka rela tanpa ada paksaan. Maksudnya adalah kebebasan para pihak untuk berkehendak dalam melakukan transaksi muamalat. Jika adanya indikasi pemaksaan dalam akad muamalat maka akad tersebut dianggap tidak sah.

c. Muamalat dilaksanakan atas dasar pertimbangan mendatangkan manfaat dan menghindari kerugian (madharat) dalam kehidupan masyarakat. Karena tujuan muamalat adalah untuk mewujudkan kemaslahatan.

d. Muamalat dilaksanakan dengan memelihara nilai keadilan. Menghindari unsur-unsur penganiayaan, unsur-unsur pengambilan kesempatan dalam kesempitan (Maulan, 2019).

Jual beli atau perdagangan dalam Islam istilah Fiqh disebut $a l-b a{ }^{\prime} i$ yang menurut etimologi berarti menjual atau mengganti. Wahbah alZuhaily mengartikannya secara bahasa dengan "menukar sesuatu dengan sesuatu yang lain". Kata $a l-b a$ ' $i$ dalam Arab terkadang digunakan untuk pengertian lawannya, yaitu kata al-syira' (beli) (Ghazaly et al., 2010). Dengan demikian, kata al-bai berarti jual beli, tetapi sekaligus juga berarti beli. Sebagian ulama mendefinisikan bahwa jual beli secara Syar'i sebagai akad yang mengandung sifat menukar satu harta dengan harta yang lain dengan cara yang khusus (Ghazaly et al., 2010).

Jual beli (al-bay) secara bahasa artinya memindahkan hak milik terhadap benda dengan akad Saling mengganti, dikatakan: " $B a$ ' $a$ asysyaia” jika mengeluarkannya dari hak miliknya, dan ba'ahu jika dia membelinya dan memasukannya kedalam hak miliknya, dan ini masuk dalam kategori nama-nama yang memiliki lawan kata jika disebut ia mengandung makna dan lawannya seperti perkataan al-qur'an yang berarti haid dan suci (Azzam, 2010). Menurut istilah yang dimaksud dengan jual beli adalah sebagai berikut (Suhendi, 2016, 2019):

1. Menukar barang dengan barang atau barang dengan uang dengan jalan melepaskan hak milik dari yang satu kepada yang lain atas dasar saling merelakan.

2. Pemikiran harta benda dengan jalan tukarmenukar yang sesuai dengan aturan syara. Akad yang tegal atas dasar penukaran harta dengan herta, maka jadilah penukar hak milik secara tetap (Azzam, 2010).

3. Tukar menukar benda dengan benda lain dengan cara yang khusus (dibolehkan).

Perdagangan atau jual beli menurut bahasa berarti al-Bai', al-Tijarah dan al-Mubadalah, sebagaimana Allah Swt. Berfirman Al-fathir 29

"Sesungguhnya orang-orang yang selalu membaca kitab Allah dan mendirikan shalat dan menafkahkan sebahagian dari rezki yang Kami anuge- rahkan kepada mereka dengan diam-diam dan terang-terangan, mereka itu mengharapkan perniagaan yang tidak akan merugi".

Jual beli menurut ulama Malikiyah ada dua macam, yaitu jual beli yang bersifat umum dan juak beli yang bersifat khusus (Suhendi, 2016):

1. Jual beli dalam arti umum ialah suatu perikatan tukar-menukar sesuatu yang bukan kemanfaatan dan kenikmatan. Perikatan adalah akad yang mengikat dua belah pihak. Tukar-menukar yaitu salah satu pihak menyerahkan ganti penukaran atas sesuatu yang ditukarkan oleh pihak lain. Dan sesuatu yang bukan manfaat ialah bahwa benda yang ditukarkan adalah dzat (berbentuk), ia berfungsi sebagai objek penjualan, jadi bukan manfaatnya atau bukan hasilnya. 


\section{EKSISBANK Vol. 4 No. 1 Juni 2020}

2. Jual beli dalam arti khusus ialah ikatan tukar-menukar sesuatu yang bukan kemanfaatan dan bukan pula kelezatan yang mempunyai daya tarik, penukarannya bukan mas dan bukan pula perak, bendanya dapat direalisir dan ada seketika (tidak ditangguhkan), tidak merupakan utang baik barang itu ada di hadapan si pembeli maupun tidak, barang yang sudah diketahui sifat-sifatnya atau sudah diketahui terlebih dahulu.

Benda yang dibeli pun memiliki persyaratanpersyaratan yang harus dipenuhi, apabila tidak pasti ada alasan-alasan tertentu yang mengakibatkan jual beli tersebut sah dan tidak sah. Adapun benda yang di perjual-belikan adalah (Rasjid, 2010): Pertama, benda tersebut harus suci (bukan barang yang najis). Kedua, adanya manfaat. Tidak boleh menjual atau membeli sesuatu yang tidak memberikan manfaat. Ketiga, barang tersebut dapat diserahkan. Artinya barang tersebut harus ada ketika ditransaksikan, tidak boleh menjual barang yang masih belum pasti contohnya ikan yang masih berenang di lautan, karena ikan tersebut sudah pasti tidah dapan diserahkan. Pengecualian untuk bai' as-salam, yang mana jual beli dengan cara melakukan pemesanan barang terlebih dahulu dan melakukan pembayaran dimuka sedangkan pemberian barang dilakuakn diakhir pada waktu yang ditentukan. Keempat, barang tersebut merupakan kepunyaan penjual sendiri, kalaupun milik orang lain boleh asal sudah diizinkan atau diserahkan untuk menjualkannya. Kelima, barang tersebut diletahui oleh si penjual dan pembeli, baik bentuk, maupun sifat yang jelas sehingga tidak ada yang merasa dirugikan dikemudian hari

Adapun maksud dan tujuan dari penelitian ini adalah untuk mengetahui mekanisme praktek jual beli followers di media sosial Instagram dan untuk mengetahui mekanisme praktek jual beli followers di media sosial instagram dalam perspektif ekonomi Islam.

\section{METODE PENELITIAN}

Jenis penelitian ini adalah penelitian lapangan (field research) yaitu penelitian yang objeknya mengenai gejala-gejala atau peristiwa-peristiwa yang terjadi pada kelompok masyarakat.
Sehingga penelitian ini juga bisa disebut penelitian kasus atau study kasus (case study) dengan pendekatan deskriptif kualitatif (Arikunto, 2013).

Penelitian kualitatif yaitu penelitian yang menghasilkan prosedur analisis yang tidak menggunakan prosedur analisis statistik atau cara kuantifikasi lainnya. Jelas bahwa pengertian ini mempertentangkan penelitian kualitatif dengan penelitian yang bernuansa kuantitatif yaitu dengan menonjolkan bahwa usaha kuantifikasi apapun tidak perlu digunakan pada penelitian kualitatif.

Penelitian ini difokuskan pada media sosial instagram. Alasan pemilihan lokasi penelitian pada media sosial Instagram adalah Alasan lainnya, yaitu Instagram merupakan salah satu sosial media yang sangat banyak digemari oleh pengguna sosial media, Instagram juga menjadi salah satu sarana untuk media pemasaran, menjadi sarana bisnis diantaranya yaitu jual beli followers. Waktu yang digunakan dalam penelitian ini dimulai dari bulan Agustus dimulai dari pencarian informan hingga mendapatkan sumber data.

Teknik pengumpulan data merupakan cara yang dilakukan peneliti untuk mengungkap atau menjaring informasi dari responden sesuai lingkup penelitian. Berikut ini ada beberapa teknik pengumpulan data:

A. Wawancara

Penelitian ini menggunakan jenis wawancara terbuka dan terstruktur, arti dari wawancara terbuka itu sendiri adalah wawancara yang para subjeknya tahu bahwa mereka sedang diwawancarai dan mengetahui pula apa maksud dan tujuan wawancara itu (Moleong, 2017). Wawancara terstruktur adalah wawancara yang pewawancaranya menetapkan sendiri masalah da pertanyaanpertanyaan yang akan diajukan (Moleong, 2017). Penelitian ini dilakukan secara terstruktur dan terbuka, dimana yang diwawancarai baik pihak penjual maupun pembeli followers telah mengetahui apa maksud dan tujuan pewawancara dan susunan pertanyaan telah disiapkan sesuai apa yang akan ditanyakan dan apa yang ingin didapatkan untuk dijadikan sumber data. Wawancara dilakukan kepada pihak yang terlibat, yaitu penjual dan pembeli followers. Waktu dan tempat dilakukan dalam 


\section{EKSISBANK Vol. 4 No. 1 Juni 2020}

wawancara ini adalah melalui media elektronik dikarenakan jarak yang jauh dengan beberapa informan maka wawancara dilakukan dengan cara mengirimkan teks wawancara secara terstruktur yang berisi pertanyaan mengenai apa yang saja data informasi yang ingin didapatkan, dengan menggunakan email, dan menggunakan Whatsapp Messengger. Wawancara ini dilakukan satu kali pada setiap informan dalam penelitian ini terdapat 5 informan 4 dari penjual aktif dan 1 penjual aktif Followers yaitu dari agen Followers dengan nama akun Rumahnya.sosmed bernama david, Jimmy dengan nama akun The Socmed, Sandro dengan nama akun Instanet ID, Morgan dengan nama akun Pojok Sosmed dan agen followers pasif dengan nama akun Satu Media Febindaazizirochimawan dan 3 informan dari pembeli Followers.

B. Observasi

Observasi yang dilakukan dalam penelitian ini adalah jenis observasi pasif (passive participation) adalah jenis obervasi yang dalam hal ini peneliti dating di tempat kegiatan orang yang diamati, tetapi tidak ikut terlibat dalam kegiatan tersebut (Sugiyono, 2017). Maka, dalam penelitian ini peneliti hanya mengamati dan observasi secara tidak langsung melalui media sosial Instagram dan mengamati bagaimana jual beli followers dilakukan. Mengamati bagaimana perkembangan mekanisme jual beli followers dengan teknik non partisipan.

C. Dokumentasi

Dokumentasi merupakan salah satu bukti bahwa penulis benar melakukan penelitian. Dokumentasi penulis berupa foto, dan hasil dari wawancara. Dokumen yang didapat dari sini adalah mengenai dokumen dari daftar harga followers beserta kriteria followers didalamnya. Dokumen mengenai daftar pertanyaan serta isi dari hasil wawancara.

Sumber data adalah subjek dari mana asal data penelitian itu diperoleh. Dalam melakukan penelitian ini data-data yang diperlukan diperoleh dari dua sumber yaitu:

\section{A. Data Primer}

Data primer adalah data yang dikumpulkan dan diolah sendiri oleh suatu organisasi atau perorangan langsung dari objeknya. Pengumpulan data tersebut dilakukan secara khusus untuk mengatasi masalah riset yang sedang diteliti. Sumber primer dalam penelitian ini di dapat dari hasil wawancara yang dilakukan terhadap lima agen followers dan tiga pembeli followers.

B. Data Sekunder

Data sekunder adalah data yang diperoleh dalam bentuk yang sudah jadi, sudah dikumpulkan dan diolah oleh pihak lain, biasanya sudah dalam bentuk publikasi (Dewanti \& Sudiartha, 2013). Data semacam ini sudah dikumpulkan pihak lain untuk tujuan tertentu yang bukan untuk keperluan riset yang sedang dilakukan peneliti saat ini secara spesifik (Hendryadi, 2015). Sumber sekunder penelitian ini diperoleh dari data atau arsip buku-buku referensi, dan situs website.

Analisis data adalah proses mencari dan menyusun secara sistematis data yang diperoleh dari hasil wawancara, catatan lapangan, dan bahan-bahan lain, sehingga dapat mudah dipahami, dan temuannya dapat diinformasikan kepada orang lain (Sugiyono, 2017). Analisis data dalam penelitian kualitatif dilakukan sejak sebelum memasuki lapangan, selama di lapangan dan setelah selesai di lapangan. Aktivitas dalam analisis data, yaitu: data reduction, data display, dan conclusion drawing/verification (Sugiyono, 2017).

\section{A. Data Reduksi (Data Reduction)}

Menurut Milles dan Huberman, mereduksi data adalah merangkum, memilih hal-hal yang pokok, memfokuskan pada hal-hal yang penting, dicari tema dan polanya. Dengan demikian data yang telah direduksi akan memberikan gambaran yang lebih jelas, dan mempermudah peneliti untuk melakukan pengumpulan data selanjutnya dan mencarinya bila diperlukan sehingga disusun secara sistematis dan mudah dikendalikan.

B. Penyajian data (data display)

Setelah data direduksi maka langkah selanjutnya adalah mendisplaykan data yang dapat dilakukan dalam bentuk tabel, grafik, pictogram dan sejenisnya. Melalui penyajian data tersebut maka data terorganisasikan, tersusun dalam pola hubungan, sehingga akan semakin mudah dipahami dalam rangka memperoleh kesimpulan sebagai temuan penelitian.

C. Penarikan kesimpulan atau verifikasi (conclusion drawing/verification) 


\section{EKSISBANK Vol. 4 No. 1 Juni 2020}

Langkah ketiga dalam analisis data kualitatif menurut Miles dan Huberman adalah penarikan kesimpulan dan verifikasi. Kesimpulan awal yang dikemukakan masih bersifat sementara, dan akan berubah bila tidak ditemukan bukti-bukti yang kuat yang mendukung pada tahap pengumpulan data berikutnya. Tetapi apabila kesimpulan yang dikemukakakn pada tahap awal, didukung oleh bukti-bukti yang valid dan saat peneliti kembali ke lapangan mengumpulkan data, maka kesimpulan yang dikemukakan merupakan kesimpulan yang kredibel.

Keabsahan data dalam penelitian ini ditentukan dengan menggunakan kriteria kredibilitas. Untuk mendapatkan data yang relevan, maka peneliti melakukan pengecekan keabsahan data hasil penelitian dengan cara:

A. Perpanjangan Pengamatan

Dalam penelitian ini peneliti melakukan perpanjangan pengamatan, dengan kembali lagi ke lapangan untuk memastikan apakah data yang telah penulis peroleh sudah benar atau masih ada yang salah.

B. Ketekunan Pengamatan

Meningkatkan ketekunan berarti melakukan pengamatan secara lebih cermat dan berkesinambungan. Dengan cara tersebut maka kepastian data dan urutan peristiwa akan dapat direkam secara pasti dan sistematis (Sugiyono, 2017). Meningkatkan ketekunan itu ibarat kita mengecek soal- soal, atau makalah yang telah dikerjakan, apakah ada yang salah atau tidak. Dengan meningkatkan ketekunan itu, maka peneliti dapat melakukan pengecekan kembali apakah data yang telah ditemukan itu salah atau tidak. Demikian juga dengan meningkatkan ketekunan maka, peneliti dapat memberikan deskripsi data yang akurat dan sistematis tentang apa yang diamati (Sugiyono, 2017).

C. Triangulasi

Dalam penelitian ini menggunakan triangulasi sumber. Triangulasi sumber digunakan untuk pengecekan data tentang keabsahannya, membandingkan hasil wawancara dengan isi suatu dokumen dengan memanfaatkan berbagai sumber data informasi sebagai bahan pertimbangan. Dalam hal ini penulis membandingkan data hasil observasi dengan data hasil wawancara, dan juga membandingkan hasil wawancara dengan wawancara lainnya

\section{HASIL DAN PEMBAHASAN}

A. Analisis Mekanisme Praktik Jual Beli Followers di Media Sosial Instagram.

Hasil dari wawancara serta observasi di atas penulis menyimpulkan bahwa Jual beli Followers menjadi sesuatu yang baru di dunia perdagangan khususnya media sosial Instagram. Jenis jual beli ini tidak jauh beda dengan jual beli online lainnya, yaitu dengan cara memesan barang terlebih dahulu. Pertama pembeli menghubungi pihak penjual melalui Instagram maupun contact person yang telah dicantumkan di Instagram atau website. Setelah menghubungi secara langsung maka penjual akan menawarkan beberapa kriteria yang telah dicantumkan di Instagram maupun website.

Pada jual beli followers ini terdapat 2 jenis followers yaitu followers aktif dan followers pasif. Followers aktif merupakan Followers aktif (Real Human Followers) adalah memiliki kemampuan untuk memberikan like dan comment untuk foto-foto Pembeli di Instagram Namun, mereka juga memiliki kemampuan untuk berhenti mengikuti (unfollow). Followers ini biasanya terdiri dari pengguna aktif Instagram. Dan Follower Pasif (Real Looking Followers) adalah tidak memiliki kemampuan untuk memberikan like dan comment serta berhenti mengikuti (unfollow) akun di Instagram atau followers yang tidak mempunyai pemilik dan followers ini tidak melakukan kegiatan apapun. Biasanya, followers seperti ini merupakan robot dan bukan manusia asli. Followers ini biasanya terdiri dari akun seseorang yang sudah tidak pernah dipakai, Olshop, fansbase dan juga akun orang luar negeri (Febinda, 2019).

Setelah memilih barang yang diinginkan sesuai kriteria juga harga, pihak penjual akan meminta Username serta password, adapula sebagian penjual followers yang hanya membutuhkan username saja tanpa harus dengan passwordnya. Kemudian selanjutnya proses transaksi dilakukan dengan transfer ataupun melalui pulsa dan ada pula penjual yang langsung bertemu, dan membayar sesuai dengan pemesanan. Setelah tahap metode pembayaran yang dilakukan, jika online setelah mengirimkan bukti pembayaran yang dilakukan baik berupa transfer maupun Top Up pulsa. Maka penjual langsung memproses pemesanan. Penambahan

Nindi Apridha Jamil | Analisis Mekanisme Praktik Jual Beli ...... 88 


\section{EKSISBANK Vol. 4 No. 1 Juni 2020}

followers dapat melalui sebuah aplikasi di website lalu dengan mengetikkan username serta password. Lamanya proses penambahan followers ini tergantung jenis dan banyaknya pemesanan.

Adanya jaminan yang diberikan pihak penjual hanyalah sebuah garansi yang dibuat hanya untuk pembelian followers pasif, tidak berlaku pada pembelian followers aktif dikarenakan followers aktif adalah Real Human yang bisa saja sewaktu waktu Unfollow akun si pembeli. Jaminan hanya diberikan jika dalam jangka waktu 1 sampai 2 bulan followers jika berkurang maka pihak penjual akan menambahkan lagi followers tersebut.

Keuntungan yang didapat dari sebuah jual beli followers adalah dapat meningkatkan penjualan, meningkatkan popularitas. Walaupun tetap saja jika yang dibeli adalah followers pasif, maka adanya unsur penipuan, dikarenakan followers tersebut hanya sebuah akun both yang digunakan hanya untuk menarik minat pembeli. Jika yang dibeli followers aktif maka resiko yang didapatkan adalah berkurangnya jumlah tersebut sewaktu waktu. Biasanya para pembeli menyadari bahwa transaksi yang dilakukan tidak mengandung manfaat sama sekali terkecuali hanya untuk memenuhi kebutuhan zaman atau disebut dengan trend masa kini.

B. Analisis Mekanisme Praktik Jual Beli Followers dalam Perspektif Ekonomi Islam

Kegiatan jual beli dilihat dari sudut pandang ekonomi Islam telah diatur dalam fiqih muamalah, segala bentuk muamalah itu boleh dilakukan sesuai dengan prinsip umum muamalah yang telah dijelaskan yaitu:

"Pada dasarnya, segala bentuk muamalah adalah boleh kecuali ada dalil yang mengharamkannya" (Djamil, 2013).

Aktivitas jual beli saat ini beragam dan berkembang mengikuti teknologi informasi dalam memenuhi kebutuhan duniawi yang bersifat materi, dalam Islam jual beli dianjurkan selama koridor yang diperbolehkan dan tidak ada yang dirugikan. Di dalam sebuah transaksi jual beli ada rukun dan syarat yang harus dipenuhi agar suatu jual beli tersebut dianggap sah, yaitu berdasarkan Fatwa Dewan Syariah Nasional-
Majelis Ulama Indonesia Nomor 110/DSNMUI/IX/2017 bahwa terdapat ketentuanketentuan diantaranya mengenai Shigat Al-aqd, terkait para pihak, Mustman Mabi' (objek), Tsaman (Harga). Berikut tabel kesesuaian Syariah antara ketentuan fatwa dengan mekanisme praktik jual beli followers:

Tabel 3.1

Ketentuan Shigat Al-'Aqd

\begin{tabular}{|c|c|c|c|}
\hline \multirow[t]{2}{*}{ NO } & \multirow{2}{*}{$\begin{array}{c}\text { Ketentuan Shigat Al- } \\
\text { 'Aqd }\end{array}$} & \multicolumn{2}{|c|}{$\begin{array}{c}\text { Kesesuaian } \\
\text { Syariah }\end{array}$} \\
\hline & & $\mathbf{Y a}$ & Tidak \\
\hline 1. & $\begin{array}{l}\text { Akad jual beli harus } \\
\text { dinyatakan secara tegas } \\
\text { dan jelas serta dipahami } \\
\text { dan dimengerti oleh } \\
\text { penjual dan pembeli }\end{array}$ & $\sqrt{ }$ & \\
\hline 2. & $\begin{array}{l}\text { Akad jual beli boleh } \\
\text { dilakukan secara lisan, } \\
\text { tertulis, isyarat, dan } \\
\text { perbuatan/ tindakan, serta } \\
\text { dapat dilakukan secara } \\
\text { elektronik sesuai syariah } \\
\text { dan peraturan perundang- } \\
\text { undangan yang berlaku }\end{array}$ & $\sqrt{ }$ & \\
\hline
\end{tabular}

Tabel di atas menjelaskan mengenai shigat dalam mekanisme jual beli followers hal ini berdasarkan hasil wawancara dan observasi yang telah dilakukan bahwa dalam mekanisme jual beli followers kesepakatan dilakukan melalui media elektronik dengan adanya interaksi antara penjual dan pembeli followers melalui media sosial, personal chat, maupun via website resmi. Sehingga dalam interaksi tersebut terjadi akad dan kesepakatan secara jelas dan tegas mengenai transaksi jual beli followers tersebut.

Tabel 3.2

\section{Ketentuan Terkait Para Pihak}

\begin{tabular}{|l|l|c|c|}
\hline \multirow{2}{*}{ NO } & \multicolumn{1}{|c|}{$\begin{array}{c}\text { Ketentuan Terkait } \\
\text { Para Pihak }\end{array}$} & \multicolumn{2}{|c|}{$\begin{array}{c}\text { Kesesuaian } \\
\text { Syariah }\end{array}$} \\
\cline { 3 - 4 } & Ya & $\begin{array}{c}\text { Tida } \\
\text { k }\end{array}$ \\
\hline 1. & $\begin{array}{l}\text { Penjual (Al-Bai') dan } \\
\text { pembeli (al-musytari) } \\
\text { boleh berupa orang } \\
\text { atau yang } \\
\text { dipersamakan dengan } \\
\text { orang, baik berbadan }\end{array}$ & $\sqrt{ }$ & \\
\hline
\end{tabular}


EKSISBANK Vol. 4 No. 1 Juni 2020

\begin{tabular}{|l|l|c|c|}
\hline \multirow{2}{*}{ NO } & \multicolumn{1}{|c|}{$\begin{array}{c}\text { Ketentuan Terkait } \\
\text { Para Pihak }\end{array}$} & \multicolumn{2}{|c|}{$\begin{array}{c}\text { Kesesuaian } \\
\text { Syariah }\end{array}$} \\
\cline { 2 - 4 } & $\begin{array}{l}\text { Ya } \\
\text { hukum maupun tidak } \\
\text { berbadan hukum, } \\
\text { berdasarkan peraturan } \\
\text { perundang-undangan } \\
\text { yang berlaku. }\end{array}$ & $\begin{array}{c}\text { Tida } \\
\text { k. }\end{array}$ \\
\hline 2. & $\begin{array}{l}\text { Penjual (al-Bai') dan } \\
\text { pembeli (al-musytari) } \\
\text { wajib cakap hukum } \\
\text { (ahliyah) sesuai } \\
\text { dengan syariah dan } \\
\text { peraturan perundang- } \\
\text { undangan yang berlaku }\end{array}$ & $\checkmark$ \\
\hline 3. & $\begin{array}{l}\text { Penjual (al-Bai') dan } \\
\text { pembeli (al-musytari) } \\
\text { wajib memiliki } \\
\text { kewenangan (wilayah) } \\
\text { untuk melakukan akad } \\
\text { jual beli, baik } \\
\text { kewenangan yang } \\
\text { bersifat ashliyyah } \\
\text { maupun kewenangan } \\
\text { yang bersifat } \\
\text { niyabiyyah, seperti } \\
\text { wakil. }\end{array}$ & & $\checkmark$ \\
\hline
\end{tabular}

Tabel di atas menunjukan adanya ketidaksesuaian syariah mengenai ketentuan terkait para pihak bahwa pada kenyataannya seorang penjual maupun pembeli tidak memiliki cakap hukum terhadap hukum syariah maupun perundang undangan yang berlaku. Juga terkait dengan kewenangan yang bersifat ashliyyah maupun niyabiyyah, berkedudukan pemilik ataupun wakil dari pemilik karena followers bukanlah seutuhnya milik dari penjual maupun pembeli, karena followers tersebut bersifat fleksibel yang dapat berubah sesuai jenisnya aktif maupun pasif. Jika dalam followers pasif ada kemungkinan dapat dikatakan bisa dimiliki tetapi untuk followers aktif, tetap saja kendali dari akun aktif tersebut adalah pemilik akunnya sendiri yang bisa saja suatu saat Unfollow, sesuai resiko yang didapatkan dalam jual beli followers ini.

Tabel 3.3

\section{Ketentuan Terkait Mutsman (Mabi') atau Objek}

\begin{tabular}{|l|l|c|c|}
\hline \multirow{2}{*}{ NO } & \multicolumn{1}{|c|}{$\begin{array}{c}\text { Ketentuan Terkait } \\
\text { Mutsman (Mabi') atau } \\
\text { Objek }\end{array}$} & \multicolumn{2}{c|}{$\begin{array}{c}\text { Kesesuaian } \\
\text { Syariah }\end{array}$} \\
\cline { 2 - 4 } & $\begin{array}{l}\text { Ya } \\
\text { Mutsman/mabi' boleh } \\
\text { dalam bentuk barang } \\
\text { dan/atau berbentuk hak, } \\
\text { serta milik penjual } \\
\text { secara penuh. }\end{array}$ & $\sqrt{ }$ \\
\hline 2. & $\begin{array}{l}\text { Mutsman/mabi' harus } \\
\text { berupa barang dan/atau } \\
\text { hak yang boleh } \\
\text { dimanfaatkan menurut } \\
\text { syariah serta boleh } \\
\text { diperjualbelikan } \\
\text { menurut syariah dan } \\
\text { peraturan perundang } \\
\text { undangan yang berlaku. }\end{array}$ & & \\
\hline 3. & $\begin{array}{l}\text { Mutsman/mabi' harus } \\
\text { wujud, pasti/tertentu } \\
\text { dan dapat } \\
\text { diserahterimakan pada } \\
\text { saat akad jual beli } \\
\text { dilakukan atau pada } \\
\text { waktu yang disepakati } \\
\text { jika akad yang } \\
\text { dilakukan } \\
\text { menggunakan akad } \\
\text { salam ataupun istishna. }\end{array}$ & $\sqrt{ }$ \\
\hline
\end{tabular}

Tabel di atas menunjukan adanya ketidaksesuaian syariah dalah hal objek jual beli, dari hasil observasi dan wawancara penulis menganalisis bahwa dalam jual beli followers objek akad tersebut tidak bersifat ada dan nyata berwujud hanya sebuah followers saja. Kemudian bukan dari kepemilikan penjual dan tanpa sepengetahuan dari orang yang mempunyai objek tersebut, dan objek tersebut bisa saja menghilang sewaktu-waktu di karenakan sang pemilik akun meng-unfollow akun yang telah di follow. Barang yang dijadikan objek transaksi harus benar-benar ada dan nyata, hendaknya objek transaksi berupa barang yang bernilai, halal, dapat dimiliki, dapat disimpan dan dimanfaatkan sebagaimana mestinya serta tidak menimbulkan kerusakan (Mustofa, 2016), barang yang dijadikan objek transaksi merupakan milik sendiri. Maka tidaklah sah menjual barang orang lain dengan tidak seizin pemiliknya atau barang-barang yang baru 
akan menjadi miliknya, dapat diserahkan dengan cepat maupun lambat tidaklah sah (Suhendi, 2016).

Tabel 3.4

Ketentuan Terkait Tsaman (Harga)

\begin{tabular}{|l|l|c|c|}
\hline \multirow{2}{*}{ NO } & $\begin{array}{l}\text { Ketentuan Terkait } \\
\text { Tsaman (Harga) }\end{array}$ & \multicolumn{2}{|c|}{$\begin{array}{c}\text { Kesesuaian } \\
\text { Syariah }\end{array}$} \\
\cline { 3 - 4 } & $\begin{array}{l}\text { Ya } \\
\text { jual beli harus sudah } \\
\text { dinyatakan secara } \\
\text { pasti pada saat akad, } \\
\text { baik ditentukan } \\
\text { melalui tawar } \\
\text { menawar, lelang, atau } \\
\text { tender }\end{array}$ & $\sqrt{ }$ & \\
\hline 2. & $\begin{array}{l}\text { Harga perolehan } \\
\text { wajib disampaikan } \\
\text { oleh penjual hanya } \\
\text { dalam jual beli } \\
\text { amanah seperti jual } \\
\text { beli murabahah dan } \\
\text { tidak wajib dalam } \\
\text { selain jual beli } \\
\text { amanah. }\end{array}$ & $\sqrt{ }$ & \\
\hline 3. & $\begin{array}{l}\text { Pembayaran harga } \\
\text { dalam jual beli boleh } \\
\text { dilakukan secara } \\
\text { tunai, tangguh, dan } \\
\text { angsur. }\end{array}$ & & $\checkmark$ \\
\hline 4. & $\begin{array}{l}\text { Harga dalam jual beli } \\
\text { yang tidak tunai } \\
\text { boleh tidak sama } \\
\text { dengan tunai. }\end{array}$ & & \\
\hline
\end{tabular}

Tabel di atas menunjukan adanya ketidaksesuaian dalam ketentuan harga, hasil dari wawancara bahwa transaksi followers dilakukan melalui transfer dan secara tunai tidak dapat ditangguhkan maupun kredit. Kesesuaian dalam hal ini hanya terdapat pada harga yang jelas dengan maksud dalam jual beli ini penjual sudah menetapkan daftar harga sesuai kriteria followers yang akan dipesan. Lalu penjual tidak wajib menyebutkan harga perolehan karena ini bukan termasuk kedalam jual beli amanah.

Bila dilihat dari segi kemanfaatannya jual beli ini tidak mengandung manfaat, yaitu sebaliknya lebih banyak mengandung kemudhratan di dalamnya. Jual beli followers ketika orang memanfaatkan banyaknya followers untuk mengiklankan barang, brand awareness, bahkan untuk mempopulerkan diri adalah sebuah kebolehan kalau ada kemanfaatannya dan tidak melanggar syarat Islam, sesuai dengan syaratsyarat objek yang diperjualbelikan yaitu barang yang dapat diambil manfaatnya. Begitu juga ketika tujuan dari membeli followers adalah untuk bertujuan promosi yang sifatnya memperkenalkan produknya terhadap calon konsumen, karena pada dasarnya konsumenlah yang menentukan untuk membeli atau tidak, dan biasanya konsumen memilih akun jual beli yang banyak followers-nya karena dapat dipercaya.

Selain melihat dari manfaat jual beli followers di atas maka ada beberapa hal yang dapat kita perhatikan dalam jual beli followers adalah ketika seseorang pembeli membeli followers pasif untuk kepentingan promosi dan juga personal branding, bahkan untuk mempopulerkan diri, maka tujuan tersebut tidak akan tercapai kerena followers pasif yang dibelinya tidak dapat melakukan aktivitas apapun karena followers pasif adalah followers bot, karena itu maka followers tersebut tidak akan bisa melakukan aktivitas layaknya followers aktif yaitu menyukai postingan, mengomentari postingan berupa foto dan video. Maka ketika para konsumen mengetahui bahwa online shop yang membeli followers pasif dengan tujuan menarik minat beli konsumen, maka bisa berdampak hilangnya reputasi online shop tersebut dan dampak lainnya adalah akun online shop tersebut bisa dijadikan untuk menipu masyarakat yang kurang teliti dan mudah tertipu dengan banyaknya jumlah followers pada akun instagram online shop tersebut.

Kerugian lainnya adalah apabila seseorang pembeli membeli followers aktif, maka konsukuensi yang harus ditanggung adalah followers yang dibeli bisa saja meng-unfollow. Pada dasarnya followers aktif yang dibeli biasanya menyadari bahwa akunnya secara otomatis mem- follow akun yang tidak diinginkan. Dan kerugian lainnya adalah apabila penjual melakukan penipuan dengan cara mencampur followers aktif dengan followers pasif, maka konsumen mengalami kerugian. Maka apabila melihat fenomena di atas maka jual beli followers media sosial Instagram pada dasarnya lebih banyak mendatangkan kemudhratan dari pada manfaatnya. Di dalam masalah ini yang yang merasakan kerugian bukan hanya pembeli tetapi juga masyarakat umum 


\section{EKSISBANK Vol. 4 No. 1 Juni 2020}

yang kurang teliti karena bisa saja masyrakat yang kurang teliti tertipu oleh online shop dengan banyaknya jumlah followers, padahal bukanlah followers asli dari akun online shop tersebut.

Jual beli followers dalam transaksi juga mekanismenya mendekati akad salam hanya saja ada beberapa ketentuan dalam jual beli yang tidak sesuai. Jual beli tersebut tidak sah, karena tidak sesuai dengan syarat-syarat jual beli yaitu berupa mendatangkan unsur manfaat serta menghindari kemudhratan. Hal ini tidak sesuai dengan prinsip muamalah yaitu segala muamalah yang dapat merusak dan mengganggu kehidupan masyarakat tidak dibenarkan karena jual beli followers adalah bentuk jual beli yang dalam bentuk penipuan atau ketidakjujuran (pembohongan publik) dan objek yang objek yang dijual bukan pemilik dari penjual. Jual beli dalam hal kemudharatan sudah sempat dijelaskan dan diperjelelas pada surat AlMaidah ayat 2:

"Dan jangan tolong menolong dalam berbuat dosa dan pelanggaran".

Jual beli followers juga tidak berpegang pada prinsip khusus muamalah seperti yang sudah dijelaskan pada bab sebelumnya tentang prinsip khusus muamalah adanya hal yang dilarang dilakukan diantaranya Tadlis atau penipuan atas adanya kecacatan dari barang yang diperjualbelikan. Tadlis ini bisa dari penjual atau pembeli. Tadlis dari penjual berupa merahasiakan cacat barang dan mengurangi kuantitas atau kualitas barang tetapi seolah-olah tidak berkurang.

\section{A. Kesimpulan}

\section{PENUTUP}

Setelah penulis mendeskripsikan mengenai mekanisme praktik jual beli followers di media sosial Instagram, sebagaimana telah dijelaskan pada bab-bab sebelumnya maka penulis menarik kesimpulan dalam skripsi ini.

Jual beli followers merupakan bentuk perniagaan baru di media sosial khususnya Instagram. Mekanisme yang dilakukan dalam praktik jual beli followers ini dilakukan seperti jual beli online pada umumnya dengan cara memesan barang atau jenis followers yang diinginkan, followers yang diperjualbelikan terdapat 2 jenis yaitu followers aktif dan followers pasif. Kemudian proses transaksi dilakukan dengan 2 cara yaitu transfer melalui bank ataupun melalui top up pulsa. Setelah pembeli memberikan bukti transaksi maka proses penambahan followers akan dilakukan dengan waktu yang sesuai dengan jumlah pesanan. Penambahan followers dilakukan menggunakan website atau aplikasi tertentu.

Mekanisme praktik jual beli followers dalam perspektif ekonomi Islam, jual beli followers Jika ditinjau dari jual beli secara umum berdasarkan Fatwa Dewan Syariah Nasional- Majelis Ulama Indonesia Nomor 110/DSN-MUI/IX/2017 dari tabel kesesuaian pada bab sebelumnya adanya ketidaksesuaian syariah dalam jual beli Followers. Jual beli followers ini termasuk kedalam jual beli yang tidak sah dengan alasan, pertama, dikatakan tidak sah sesuai analisa dari bab sebelumnya

Diketahui bahwa praktik jual beli followers di atas secara rukun dan syaratnya tidak terpenuhi, dalam hal objek yang dipejualbelikan tidak jelas wujud maupun dalam hal status kepemilikan objek tersebut bukan seutuhnya milik penjual atau tidak adanya ijin dari si pemilik. Maka syarat dan rukun dari jual beli tersebut tidak terpenuhi. Kemudian kedua, dilihat dari sisi manfaat dalam jual beli followers ini cenderung banyak mendatangkan kemudharatan serta rawan terjadinya penipuan dan dalam transaksi ini mengandung unsur mengambil keuntungan dalam kesempitan yang mengandung tipu daya sehingga mengakibatkan salah satu pihak merugi. Hal tersebut dapat dilihat dari obyek yang diperjualbelikan tidak sesuai dengan kesepakatan di awal sehingga terdapat kerugian dari pihak pembeli mengenai berkurangnya jumlah followers yang dibelinya secara cepat tanpa diketahui pihak pembeli di awal waktu dan tidak adanya jaminan atau garansi dari pihak penjual untuk followers aktif. Jual beli ini tetap ada manfaatnya namun bersifat fiktif, bahkan dapat menimbulkan penipuan yang dapat dirugikan masyarakat dan konsumen.

\section{B. Saran}

Setelah paparan kesimpulan penelitian di atas, maka ada beberapa saran dari penyusun untuk pengguna akun media sosial Instagram terkhususkan kepada pihak pihak yang membeli followers yang menggunakannya untuk kepentingan pribadi maupun untuk membuka usaha bisnis online serta menghasilkan 


\section{EKSISBANK Vol. 4 No. 1 Juni 2020}

penghasilan yang halal dan berkah dan berikut ini adalah saran saran dari penulis.

1. Bagi para penjual followers media sosial Instagram pelajari dulu mekanisme jual beli tersebut, apakah memenuhi rukun dan syarat jual beli didalam ekonomi Islam atau belum memenuhi ketentuan tersebut. Sehingga dapat menghindar atau mencegah hal yang tidak di inginkan atau merugikan konsumen di media sosial Instagram. Bagi para penjual dalam melakukan pengiklanan atau promosi sebaiknya harus jujur, dan menjelaskan objek yang akan dijual tersebut yaitu berupa kelebihan dan juga berupa kekurangan yang dapat merugikan konsumen, serta menyediakan garansi kepada konsumen apabila ada sesuatu yang tidak diinginkan pada objek tersebut.

2. Bagi para pengguna media sosial Instagram yang membeli followers Jika menginginkan followers yang banyak dan ingin populer di media sosial khususnya di Instagram maka lebih baik gunakan cara yang manual saja yaitu dengan cara membuat suatu kreatifitas atau karya yang membanggakan dan juga sesuatu yang bermanfaat bagi masyarakat yang melihat akun tersebut atau dengan cara membuat kreatifitas yang berupa tulisan dengan kata kata menyentuh dan foto traveling atau foto dan video dengan content yang unik, sehingga orang banyak memfollow akun tersebut dan real followers yang tertarik dengan suatu hal yang dilakukan. Manfaatkan sosial media tersebut dengan baik dan benar dengan membuat dampak positif bagi para pengguna Instagram. Dan jadikanlah manfaat media Instagram tersebut sebagai sarana menimba ilmu agama dan belajar pengetahuan yang lain dan dapat bermanfaat baik bagi diri sendiri maupun orang lain.

C. Rekomendasi

Berdasarkan kesimpulan yang telah dipaparkan, maka penulis mengajukan rekomendasi yang dipandang berguna bagi penelitian selanjutnya dan bagi pihak penjual maupun pembeli:

1. Hasil penelitian menunjukan bahwa mekanisme praktik jual beli followers merupakan jual beli yang tidak sah, dikarenakan faktor objek jual beli dan manfaat dari jual beli tersebut. Maka penulis memberikan rekomendasi kepada penjual agar lebih mengetahui mengenai jual beli yang telah ditetapkan dalam ekonomi Islam. Kemudian bagi pembeli diharapkan lebih mengutamakan tujuan yang tidak menimbulkan kerugian bagi siapapun.

2. Untuk peneliti selanjutnya, peneliti mengharapkan adanya kajian yang lebih detil dalam melakukan penelitian khususnya mengenai jual beli followers agar adanya suatu inovasi dalam sebuah penelitian dan hasil dari penelitian tersebut lebih beragam. Serta menggali pustaka dengan luas guna kualitas dalam melakukan penelitian.

\section{DAFTAR PUSTAKA}

@TrikPhotoshopID, \& @BisnisAnakMuda. (2014). Jago Jualan di Instagram.

Anisa, N. (2018). Tinjauan Hukum Islam Tentang Praktik Jual Beli Follower, Likes, dan Viewer di Media Sosial Instagram. UAIN Raden Intan Lampung.

Arikunto, S. (2013). Prosedur Penelitian Suatu Pendekatan Praktek (1st ed.). Rineka Cipta.

Azzam, A. A. M. (2010). Figh Muamalat Sistem Transaksi Dalam Fiqh Islam (1st ed.). Amzah.

Basyir, A. A. (2000). Asas-asas hukum Muamalah. UII Press.

Bombang, S. (2013). Prospek Perbankan Syariah Di Indonesia. Jurnal Diskursus Islam, 1(2), 265-288. https://doi.org/10.24252/JDI.V1I2.6632

Dewanti, M., \& Sudiartha, G. (2013). Pengaruh Cash Ratio, Debt To Equity Ratio, Dan Earning Per Share Terhadap Cash Dividend Pada Perusahaan Food and Beverages Yang Terdaftar Di Bursa Efek Indonesia Selama Periode 2005-2010. E-Jurnal Manajemen Universitas Udayana, 2(2), 241867.

Djamil, F. (2013). Hukum Ekonomi Islam. Sinar Grafika Offset.

Febinda. (2019). Wawancara; Penjual Pasif Followers Instagram melalui Whatsapp Messenger.

Ghazaly, A. R., Ihsan, G., \& Shidiq, S. (2010). Figh Muamalah. Kencana Prenada Media Group. 
EKSISBANK Vol. 4 No. 1 Juni 2020

Haris.com, A. F. (2019). Wawancara; Jual Beli Follower melalui Whatsapp Messenger.

Hendryadi, S. (2015). Metode Riset Kuantitatif Teori dan Aplikasi Pada Penelitian Bidang Manajemen dan Ekonomi Islam. Prenadamedia Group.

Herdani, M. (2014). Jual Beli Follower Sosial Media Twitter dalam Perspektif Hukum Islam. UIN Sunan Kalijaga.

Irma, A. (2017). Peran Instagram Sebagai Media Komunikasi Pemasaran Bisnis Online (Studi Deskriptif Kualitatif Pada Bisnis Online Beautyhomeshop). Jurnal Online Kinestik, 4(2), 1-12.

Khoiriyah, U. (2018). E-Commerce dalam Hukum Islam: Studi Analisis Atas Pandangan Abdul Halim Barkatullah dan Teguh Prasetyo. Istidlal: Jurnal Ekonomi Dan Hukum Islam, 2(2), 120-135. https://doi.org/10.35316/istidlal.v2i2.112

Maulan, R. (2019). Pengantar Fiqih Muamalah 1 .

https://www.takafulumum.co.id/upload/liter asi/pengetahuan/Pengantar Fiqh Muamalah 1.pdf

Moleong, L. J. (2017). Metodologi Penelitian Kualitatif. Remaja Rosdakarya.

Munib, A. (2018). HUKUM ISLAM DANMUAMALAH (Asas-asas hukum Islam dalam bidang muamalah). Al-Ulum: Jurnal Penelitian Dan Pemikiran Ke Islaman, $\quad 5(1), \quad 72-80$. https://doi.org/10.31102/alulum.5.1.2018.72 $-80$

Mustofa, I. (2016). Figh Muamalah Kontemporer. Rajawali Pers.

Rasjid, S. (2010). Fiqih Islam (46th ed.). Sinar Baru Algesindo.

RI, K. P. (2014). Panduan Optimalisasi Media Sosial untuk Kementrian Perdagangan RI. Pusat Humas Kementrian Perdagangan.

Romansyah, H. (2015). Pasar Modal Dalam Perspektif Islam. Mazahib; Jurnal Pemikiran Hukum Islam, 14(1). https://doi.org/10.21093/mj.v14i1.332

Sugiyono. (2017). Metode Penelitian Kuantitatif, Kualitatif, dan $R \& D$. Alfabeta.
Suhendi, H. (2016). Fiqh Muamalah. Raja Grafindo Persada.

Suhendi, H. (2019). Fiqih Muamalah. PT Raja Grafindo Persada.

Nindi Apridha Jamil | Analisis Mekanisme Praktik Jual Beli ...... | 94 